\title{
Technical Efficiency in Iran's Industry Sector: A Stochastic Frontier Analysis (SFA) Approach
}

\author{
Mansour Asgari ${ }^{1}$
}

M.asgari@itsr.ir

\begin{abstract}
Nowadays, the most important factor affecting production is efficiency, which recovers economic performance, adjusts prices, enhances competitiveness, and improves social welfare and growth sustainability by influencing the production level. This paper aims to estimate the technical efficiency of production in Iran's industrial sector by implementing Stochastic Frontier Analysis (SAF); To this end, the Translog Function is used to estimate the production and technical performance of the Iranian industry sector in terms of four-digit International Standard Industrial Classification (ISIC) codes for the period 2010-2018. Accordingly, the panel data technique is applied to estimate the technical efficiency and production function Frontier Production Functions, the estimator of maximum likelihood variables of using value-added variables, labor force, capital, and energy based on four-digit ISIC codes. The results show that the chemical, petroleum, and coal industries ranked first in efficiency; textile manufacturing, clothing industry, wood, and cork industry, manufacture of articles of straw and plaiting materials, and paper and paper products ranked second in efficiency; Coke production and refined petroleum products, chemicals and chemical products, and manufacturing other non-metallic mineral products ranked third in efficiency; and lastly, manufacturing basic metals and fabricated metal products, except machinery and equipment, ranked as fourth.
\end{abstract}

Keywords: Stochastic Frontier Analysis (SAF), Technical Efficiency, Industry Sector, Maximum Likelihood Estimation, Panel Data.

JEL Classification: C23, D24, Q12.

1. Assistant Professor, Institute for Trade Studies and Research (ITSR), Tehran, Iran. 


\section{كارايى فنى بخش صنعت ايران:رهيافت تحليل مرزى

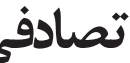

M.asgari@itsr.ir

منصور عسگَرى

استاديار موسسه مطالعات و يروهش عهاى بازركانى، تهران،

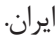

مقاله بزوهشى

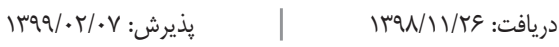

جكيده: امروزه مهمترين عامل موثر بر توليد، كارايى است كه با اثرگذارى بر سطح توليد

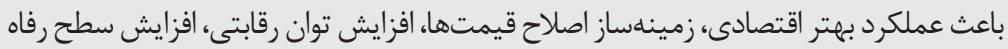

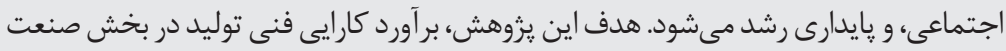

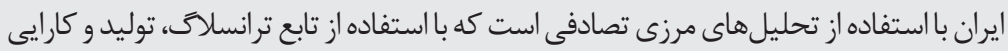

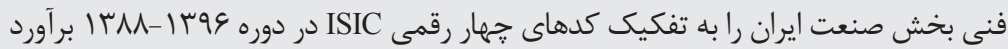

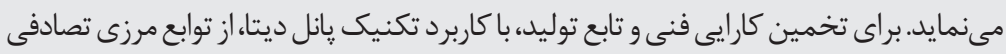

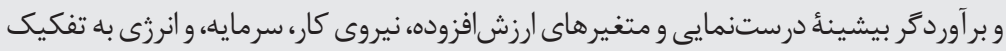

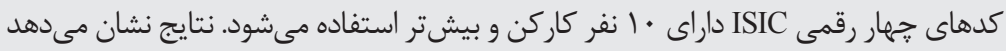

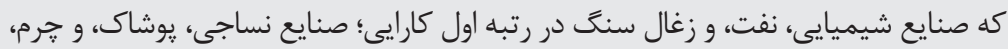

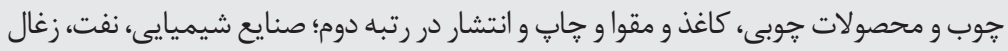

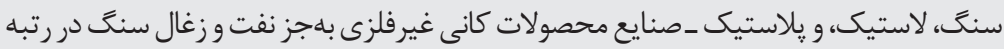

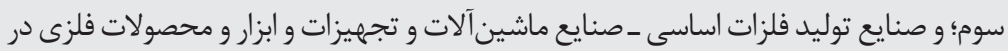
رتبه جهارم كارايى قرار دارند.

كليدوازهها: تحليل مرزى تصادفى، كارايى فنى، بخش صنعت، بيشينهُ درستنمايى، يانل ديتا.

طبقدبندى Q12, D24, C23 :JEL ديثا. 
بخش صنعت بلهور بالقوه داراى توانمندىهاى فراوانى است و موتور رشد و توسعه پايدار هر كشور است. اين بخش از نظر تنوع و فراوانى محصولات توليدى و قدرت اشتغالزايى بسيار مهرم است. بهون. رشد و توسعه يايدار در كشورها، بلويزه در كشورهاى درحالتوسعه، به بالا بودن كيفيت و كمّيت

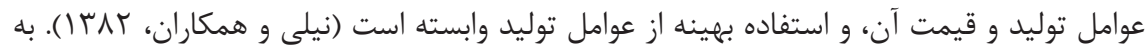
همين دليل است كه اغلب كشورها ساختار توليد خود را بر مبناى توسعه منابع برنامهريزى مى كنيند

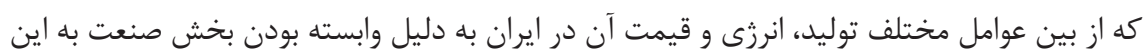
عامل، يكى از مهممترين عوامل توليد، در رشد و توسعه يايدار اقتصادى است. در فرايند توليد، مهمرترين عامل موثر بر توليد، كارايى است كه با اثرخذارى بر سطح توليد، باعث بهبود وضعيت اقتصادى ميىشود.

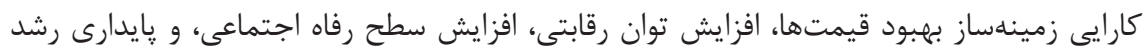

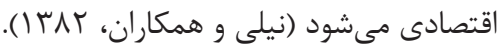
از طرفى، نقش و سهمم صنعت در اقتصاد ملّى ناشى از تاثيرى است كه در رشد و توسعه ايفا

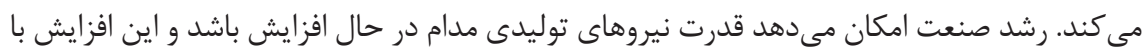

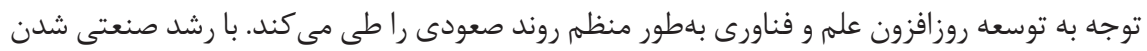

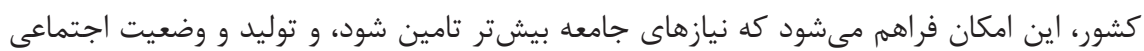
ارتقا يابد. فرايند توليد صنعتى كه فرايندى فنىانسانى است، از نظر اقتصادى، بلويزه در سطح كلان

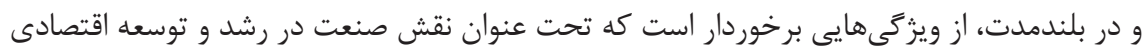

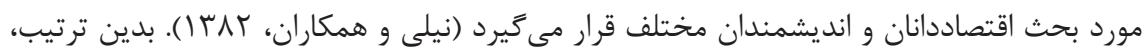
اثر بلندمدت صنعتى شدن كشورهاى درحالتوسعه، تنها در ايجاد و بهبود در توليد صنعتى نيست،

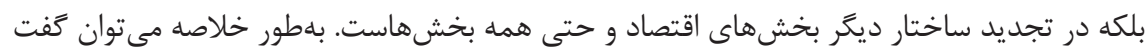

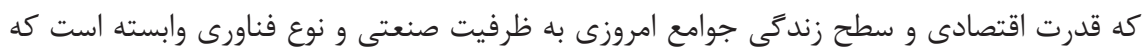

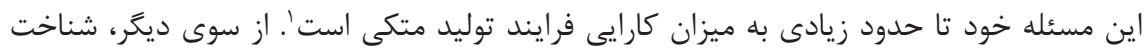
كافى از وضعيت عملكرد بخش صنعت، سياستخذار را در تهيه بستههاى حمايتى براى بهبود وضعيت

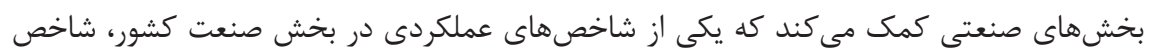
كارايى فنى است. در شرايط كنونى كشور ايران كه احتمال افزايش قيمت حاملهاى إنى انرزى و تعديل 
قيمت اين حاملها وجود دارد، داشتن تصويرى از وضعيت كارايى و عملكرد بخشهاى مختلف صنعتى مى تواند به عنوان يك شاخص و مولفه در كنار ساير مولفهها، نحوه و ميزان توزيع كمكهاى حمايتى ومائى را براى سياستخذار مشخص نمايد.

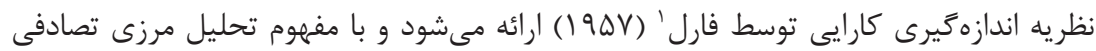
(SFA)

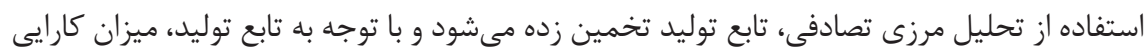

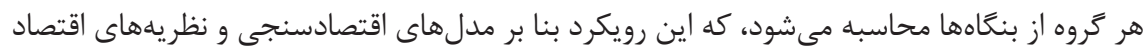

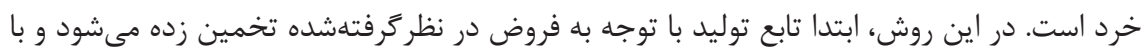

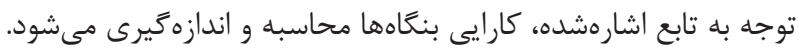

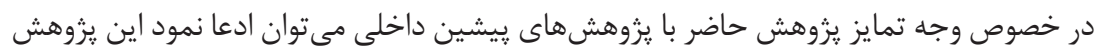

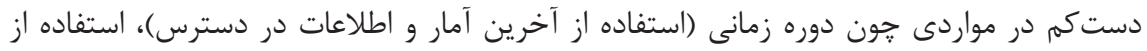

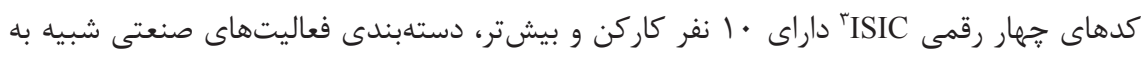

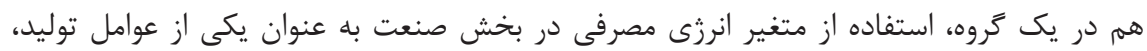
مقايسه روشهاى محاسبه كارايى، و استفاده از كليه فعاليتهاى بخش صنعت در محاسبههاى خود و نه فعاليتهاى منتخب، با ساير يروهشها تفاوت دارد، و مى توان كفت كه دست كم در موارد بيانشده،

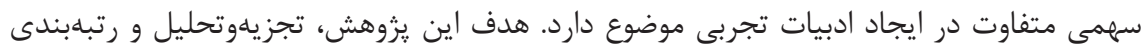

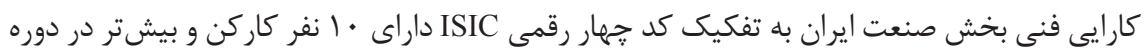

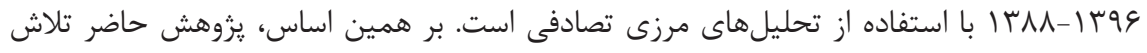

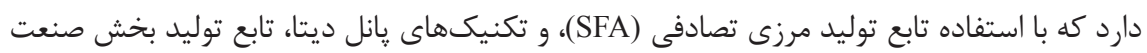

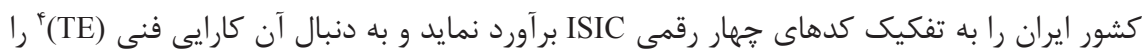

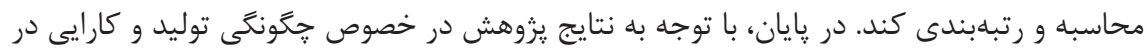

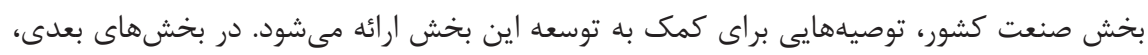

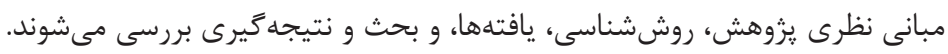

1. Farrell

2. Stochastic Frontier Analysis

3. International Standard Industrial Classification 


\section{مبانى نظرى يزووهش}

همواره ارتباط بسيارى بين دو وازه بهرهورى و كارايى وجود داشته و همين امر موجب شده است كه بحثهاى بسيارى ييرامون تشخيص و جداسازى اين دو وازه اقتصادى انجام گيرد. اقتصاددانان بلهطور معمول كارايى را تحت شرايط رقابت كامل تعريف مى كنند. به نظر هايك' (949 (1)، كارايى

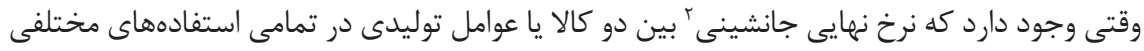

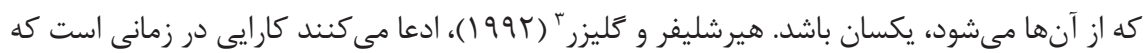

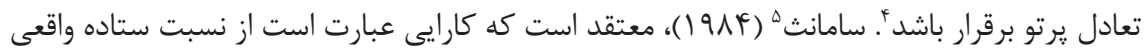

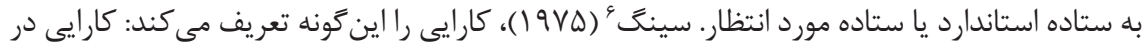
اقتصاد به مفهوم تخصيص بهينه منابع است و در مجموعهاى از فعاليتها، هنگامى يك فعاليت كاراست

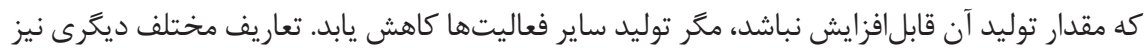

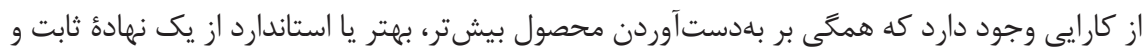

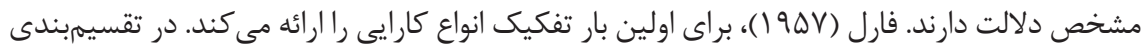

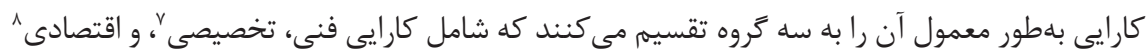

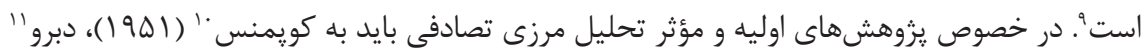

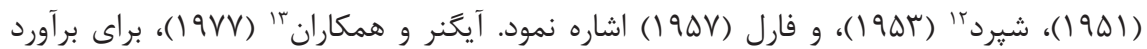

1. Hayek

2. Marginal Rate of Substitution

3. Hirshleife \& Glazer

5. Sumanth f. افزايش در مطلوبيت يك يا جند شخص بدون كاهش در مطلوبيت ديكران امكانيذير نيست.

6. Singh

7. Allocative

8. Economic

9. كارايى فنى عبارت است از بيشترين توليد ممكن كه مىتوان از مقدار مشخصى از عوامل توليد بهدست آورد.

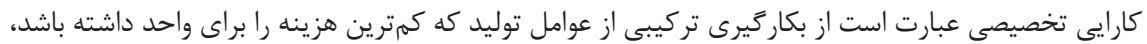
بهطورى كه با توجه به سطح مشخص محصول، بيشترين سود بهدست آيد. و كارايى اقتصادى عبارت است از 10. Koopmans

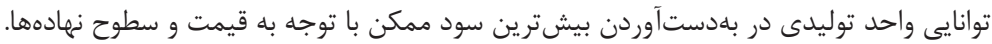

11. Debreu

12. Shephard

13. Aigner et al. 
كارايى و تخمين مدل تابع توليد مرزى تصادفى' برحسب تعريف فارل (9DV (1) نتيجه كيرى مى كنند

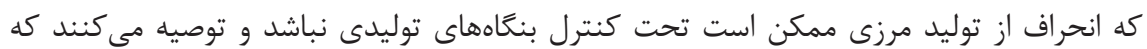

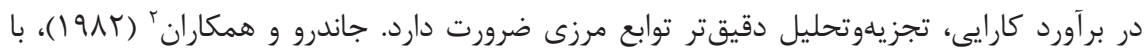

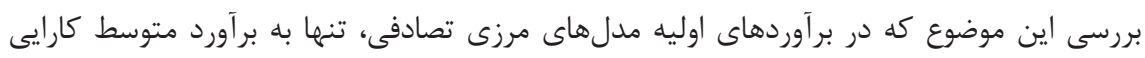
تمام بنعًاههاى مورد بررسى اكتفا مى گرديد و مشخص نبودن اينكه آيا عملكرد مشاهدهشه يكى

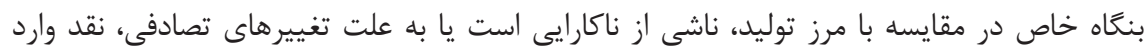

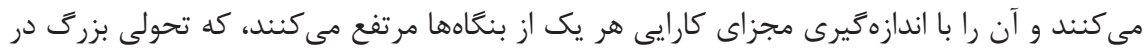

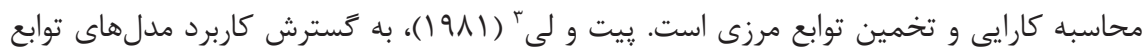

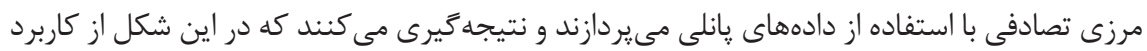

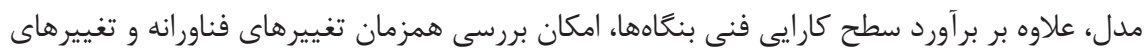

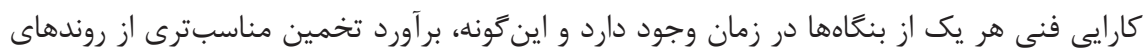

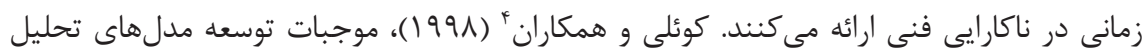

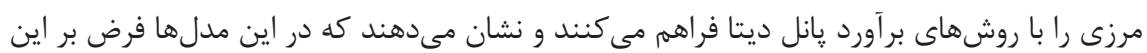
است كه كارايى فنى در طول زمان تغيير نمى كند (كارايى فنى در طول زمان ثابت مى ماند)، و و آن ران ران اصلاح و كسترش مى دهند و تصريح مى كنند كه ساختار فناورى در طى زمان متغير است، كه كورنول

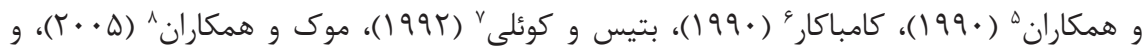

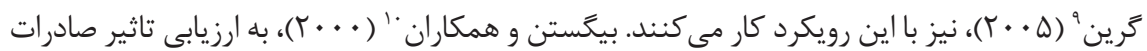

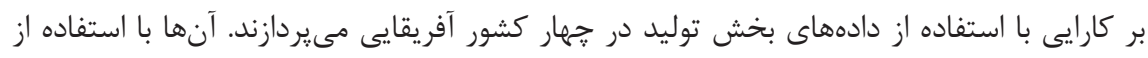

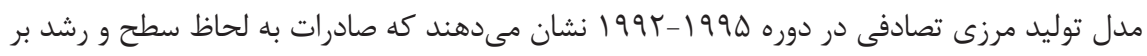

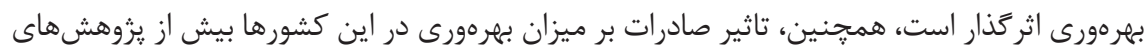

1. Formulation and Estimation of Stochastic Frontier Production Models

2. Jondrow et al.

3. Pitt \& Lee

4. Coelli et al.

5. Cornwell et al.

6. Kumbhakar

7. Battese \& Coelli

8. Mok et al.

9. Greene

10. Bigsten et al. 
مشابه در ساير مناطق است. محدنور و اسماعيل' (V +. (Y)، در ارزيابى كارايى فنى در صنايع مالزى نتيجه مى گيرند كه بيشتر بنگاهها در مالزى بلنسبت ناكارا هستند و اندازه بنگاهها و سطح فناورى

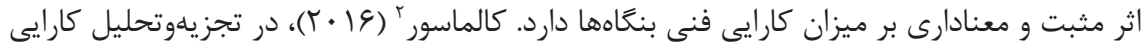

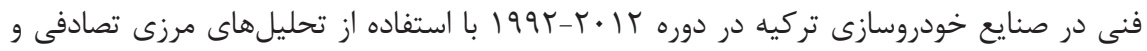

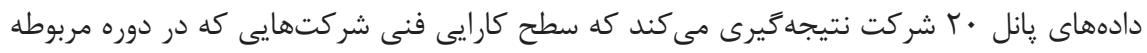
در بخش خودروسازى تركيه فعاليت مى كنند، با ناكارامدى مواجه هستند و رابطه مثبت بين نسبت

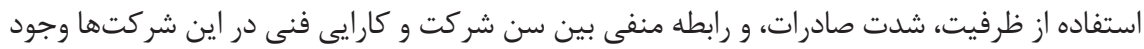

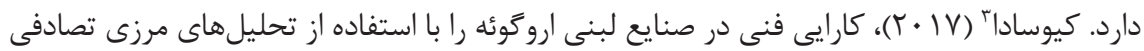

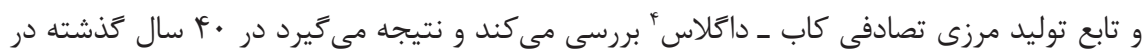
اين صنايع بهطور مداوم كارايى فنى در حال رشد است كه از كاربرد فناورىهاى جديد ناشى مىشود

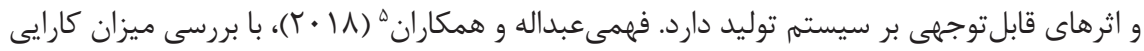

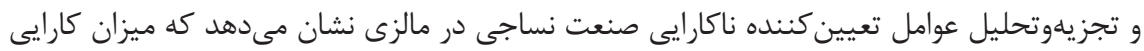
صنعت نساجى در مالزى حدود ND| • است و متغيرهاى نسبت سرمايه به نيروى كار، دستمزد، و هزينه نقش مهمى در كاهش ناكارامدى صنعت نساجى در مالزى دارند.

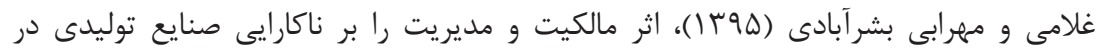
استانهاى مختلف ايران با استفاده از توابع توليد مرزى تصادفى محاسبه مى كنيند و نشان مى ميدهند كه متوسط كارايى فنى در استان تهران بيشترين و در استان كهيَيلويه و بويراحمد كمترين است، و و مديريت دولتى بر كارايى اثر منفى دارد. سجادىفر و همكاران (4 (1)، نتيجه

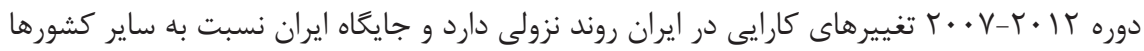

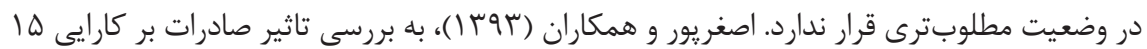
زيربخش صنعتى محصولات شيميايى و فلزات اساسى در سطح كدهاى جهار رقمى مىيردازند و براى

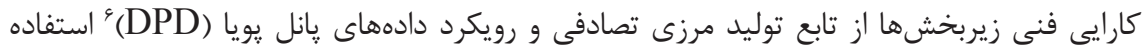
مى كنند. آنها نشان مى دهند كه صادرات، واردات فناورى خارجى، سرمايه انسانى، و اندازه بنعاه اثر

1. Mohd Noor \& Ismail

2. Çalmaşur

3. Quesada

4. Cobb-Douglas

5. Fahmy-Abdullah et al.

6. Dynamic Panel Data 
مثبت و معنادارى بر كارايى زيربخشهاى صنعتى محصولات شيميايى و فلزات اساسى ايران دارد.

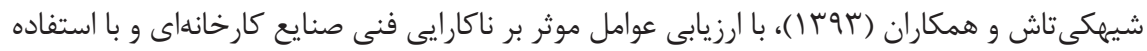

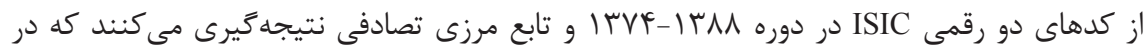

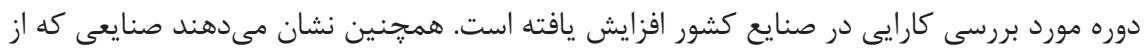

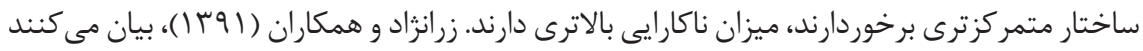

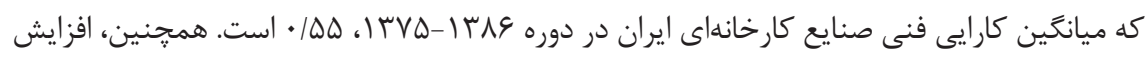

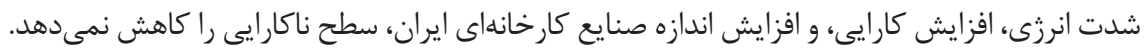

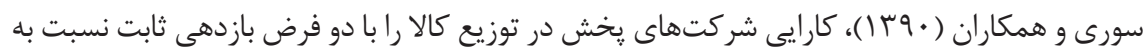

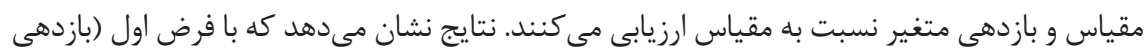

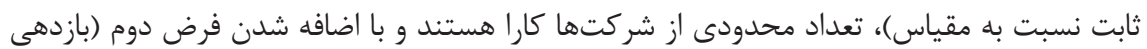
متغير نسبت به مقياس)، شركتهاى بيشترى در گروه شركتهاى كارا قرار مى كيرند.

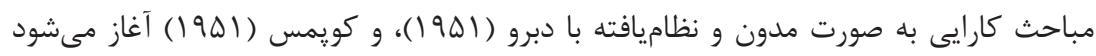

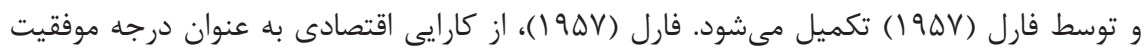
بهرهبردار در كمينه كردن هزينه توليد ميزان معينى از محصول ياد مى كند. وى كارايى اقتصادى را به

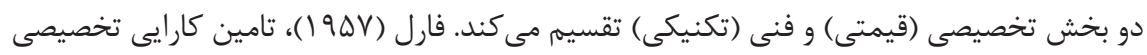

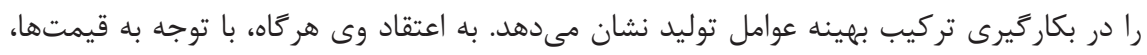
نهادهها به نحوه مناسب تخصيص يابد، سود بيشينه مىشود، و مىتوان كفت كارايى تامين است. از طرف ديكر، واحدى از نظر فنى كاراست كه بتواند از مصرف ميزان معينى از عوامل توليد، بيشترين مهابين

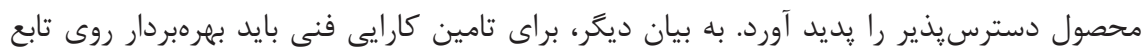

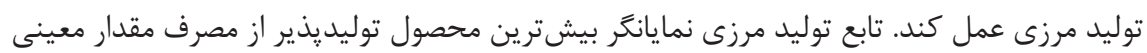
از عوامل توليد است. بنابراين، بهرهبردارى از نظر اقتصادى كاراست كه با عمل روى تابع توليد كاراو و و انتخاب تركيب بهينه عوامل توليد، موجب بيشينه شدن سود و در نتيجه، تامين كارايى اقتصادى شود.

\section{تابع توليد مرزى تصادفى}

اين روش بنا بر مدلهاى اقتصادسنجى و نظريههاى اقتصاد خرد است و مىتواند در تحليلها از

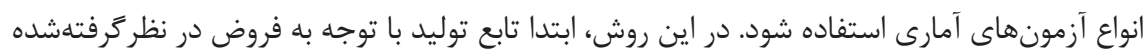
تخمين زده مىشود و با توجه به تابع اشارهشده، كارايى اندازهكيرى مىشود. همجنين، برترى مدل هاى

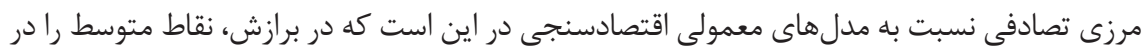


نظر نمى گيرند، بلكه نقاط مرزى و سرحد را لحاظ مى كنند. تحليل مرزى تصادفى بهطور مستقل توسط

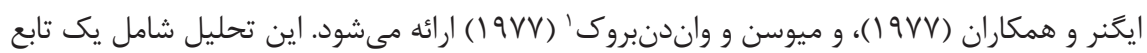

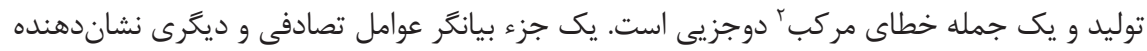
ناكارايى فنى است. در روش يارامتريك آمارى دليل تفاوت بين تابع واقعى و تابع مرزى عامل ناكارايى

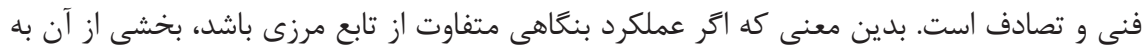

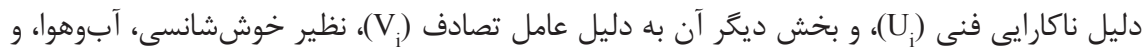

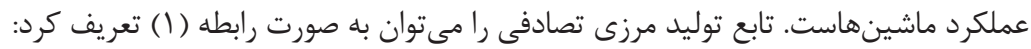

$Y_{i}=f\left(X_{i}, \beta\right) \exp \left(V_{i}, U_{i}\right) \quad i=1,2,3, \ldots, N$

: محصول بنكاه : Yi

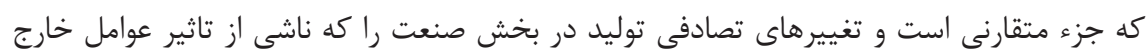

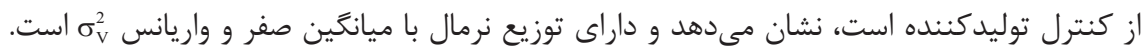
Ui به كارايى فنى توليد مربوط مىشود، اين جزء داراى توزيع نيمدنرمال با ميانكَين صفر و واريانس o $\sigma_{U}^{2}$

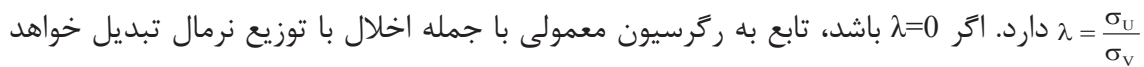
شد، و Vi نمايانكر بخشى از جمله خطا است كه مربوط به متغيرهاى تصادفى كنترلنايذير هر بنگاه

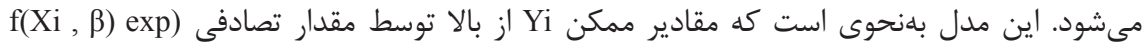
(Vi

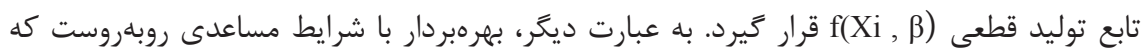

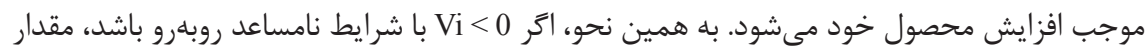
محصول مرزى او زير تابع توليد معين f(Xi, ر) واقع خواهد شد (نمودار ()). در تابع مرزى تصادفى

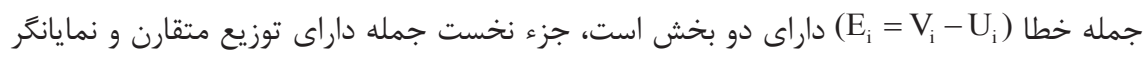

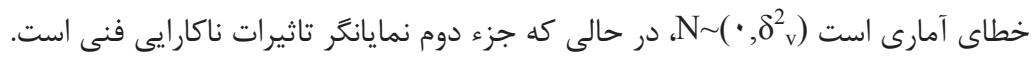




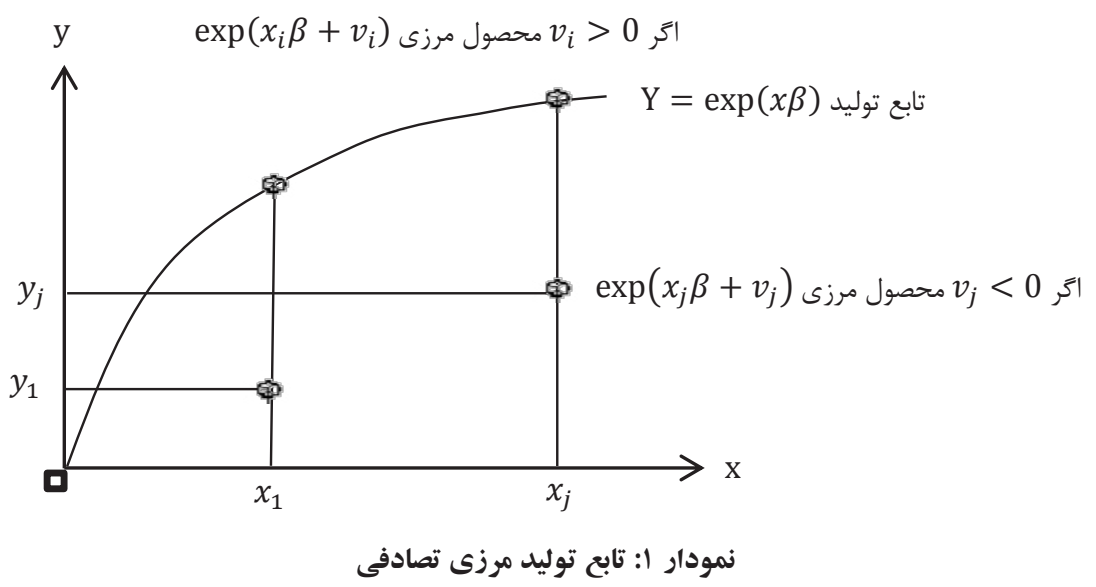

در نمودار (Y)، تابع توليد مرزى يك فرايند توليدى ساده با يك عامل توليد (X) و يك محصول توليدى (y) نشان داده شده است. اين تابع مرزى، بيشترين توليد دسترسيذير را از سطوح مختلف عوامل توليد در فناورى معينى نشان مى دهد.

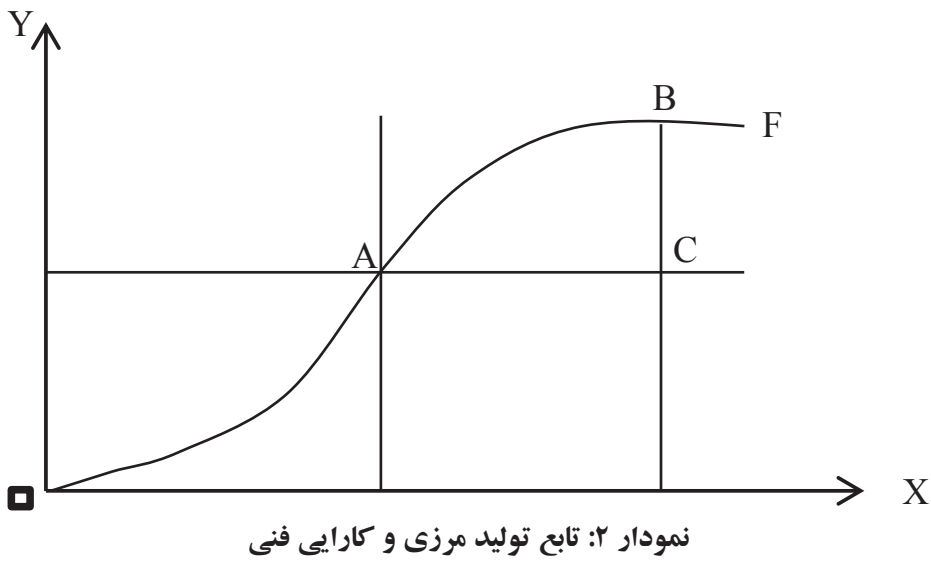

بر اساس اين، بنكاههايى كه روى تابع توليد مرزى قرار دارند، از كارايى فنى برخوردارند. بدين معنا

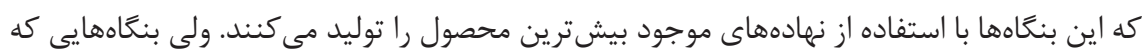
در زير اين تابع قرار دارند، با ناكارايى مواجه هستند. با در نظرگرفتن مطالب يادشده مىتوان جنين 
كفت كه بنعًاه در نقطه C با مشكل ناكارايى مواجه است، برخلاف نقاط A و B. پس نقاط روى تابع

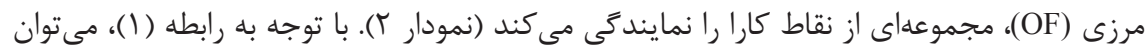
كَفت انحراف نقاط مشاهدهشه از تابع توليد مرزى به دو بخش U و

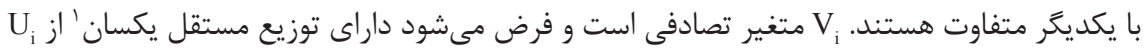

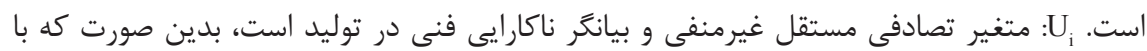
فرض سطح معينى از فناورى و نهاده ممكن است توليد از مقدار بالقوهاش كمتر شود. همجنين، فرض

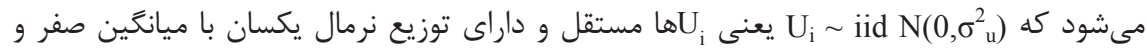

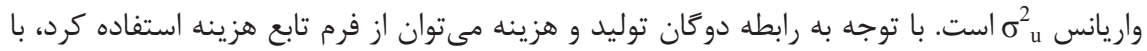

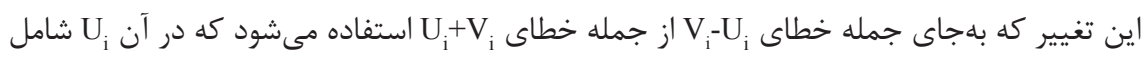
اطلاعات مربوط به ناكارايى فنى بنحاه iام است. متغير Yit توليد واقعى هر بنَاه يا بخش است، بيشترين توليد امكان يذير با استفاده از فناورى موجود است كه خواهيم داهن داشت

$T E=\frac{\mathrm{Y}_{\mathrm{it}}}{\mathrm{Y}_{\mathrm{it}}^{*}}, \quad 0 \leq \mathrm{TE} \leq 1$

$\mathrm{Y}_{\mathrm{it}}=\mathrm{Y}_{\mathrm{it}}^{*} \times \mathrm{TE}=\left(\mathrm{X}_{\mathrm{it}}, \beta\right)$

$Y_{\text {it }}=f\left(X_{i t}, \beta\right) \exp \left(-u_{i t}\right), u \geq 0$

$\mathrm{Y}_{\mathrm{it}}=\mathrm{f}\left(\mathrm{X}_{\mathrm{it}}, \beta\right) \exp \left(\mathrm{v}_{\mathrm{it}}\right) \exp \left(-\mathrm{u}_{\mathrm{it}}\right), \mathrm{u} \geq 0, \mathrm{v} \leq 0$

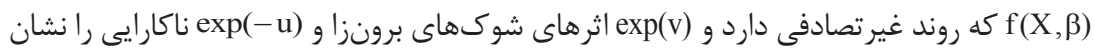
مىدهد و f(X, 3$) \exp (v)$ تابع تصادفى مرزى است. $T E=\frac{\mathrm{Y}_{\mathrm{it}}}{\mathrm{f}\left(\mathrm{X}_{\mathrm{it}}, \beta\right) \exp \left(\mathrm{v}_{\mathrm{it}}\right)}=\frac{\mathrm{f}\left(\mathrm{X}_{\mathrm{it}}, \beta\right) \exp \left(\mathrm{v}_{\mathrm{it}}\right) \exp \left(-\mathrm{u}_{\mathrm{it}}\right)}{\mathrm{f}\left(\mathrm{X}_{\mathrm{it}}, \beta\right) \exp \left(\mathrm{v}_{\mathrm{it}}\right)}$

$\mathrm{TE}=\exp \left(-\mathrm{u}_{\mathrm{it}}\right)$

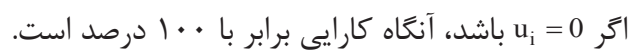




\section{روش تحليل :وششى دادهها}

روش تحليل يوششى دادهها (DEA)' توسط جارنز و همكاران ' (91V ())، با جامعيت بخشيدن به

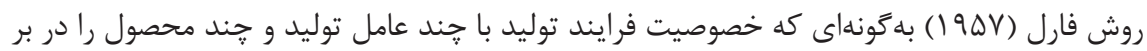
گيرد، به ادبيات اقتصادى اضافه مىشود. اين روش كه بيشتر به عنوان روش اندازهكيرى كارايى در

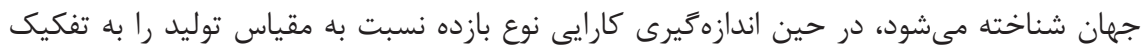

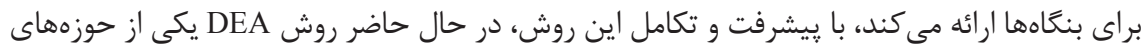

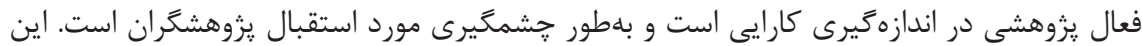
روش كه تكنيك برنامهريزى خطى را بكار مى گيرد از جمله روشهاى نايارامتريك تخمين توابع توليد يكسان است.

نمودار (بّ)، نشاندهنده تركيب استفاده از عوامل X و X براى توليد يك واحد محصول (Y) در بنگًاهاى مختلف است، با اتصال نقاطى كه به محورها و مبدا مختصات نزديكتر هستند، تابع

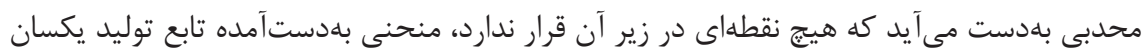

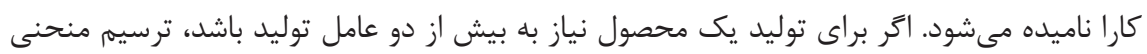

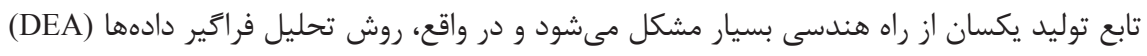

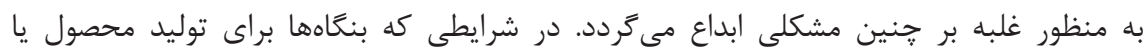
محصولات خود به بيش از يك عامل توليد نياز داشته باشند، هر بنكاه توليدى با توجه به نوع و ميزان

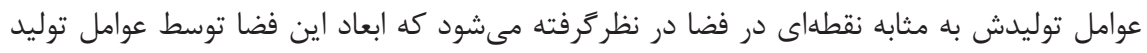

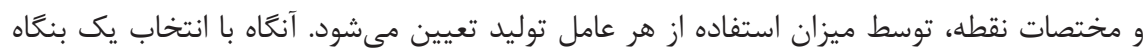
توليدى به عنوان بنگًاه مورد بررسى به كمك برنامهريزى خطى، موقعيت اين بنًَاه توليدى نسبت به ميه

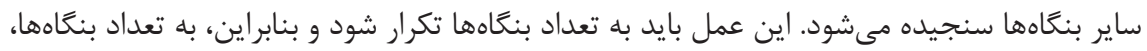
مدل برناملريزى خطى وجود خواهد داشت. 


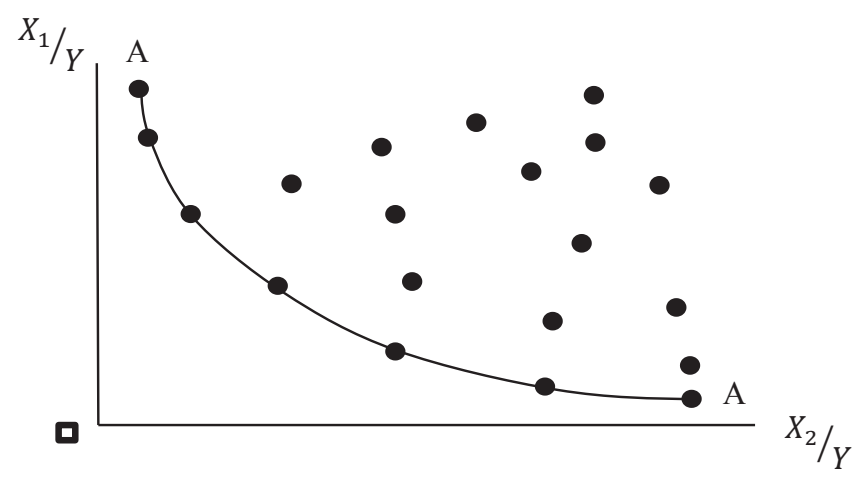

نمودار "ז: منحنى توليد يكسان كالا

در اين مدل، بنكاههايى كه بر طبق اصول كمتر ين هزينه (كارا) فعاليت مى كنند، روى تابع توليد

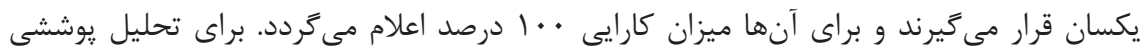

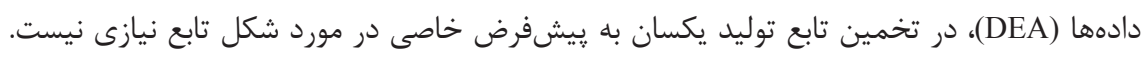

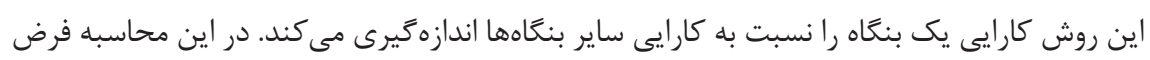

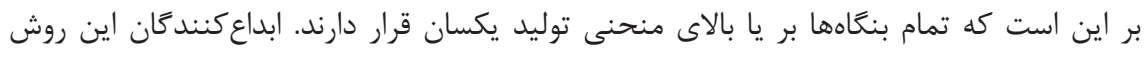

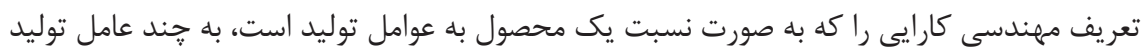

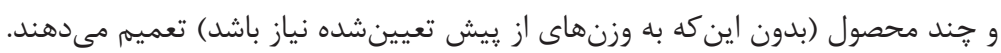

مقايسه روشهاى (SFA) و (DEA)

در روش تحليل فراگير دادهها از تكنيك برنامهريزى خطى استفاده مىشود و كارايى به وسيله

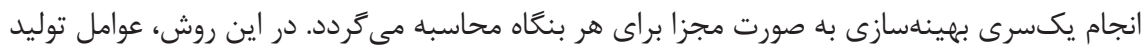

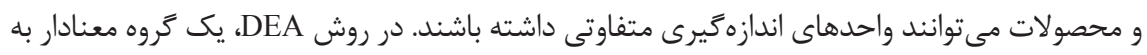

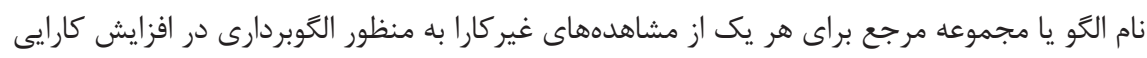

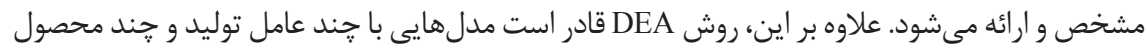

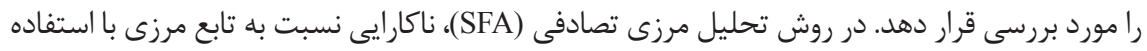

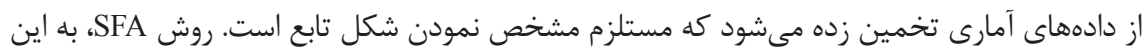

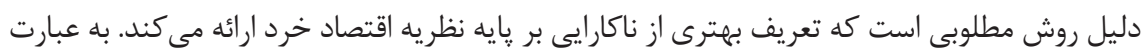

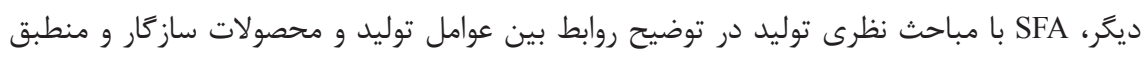




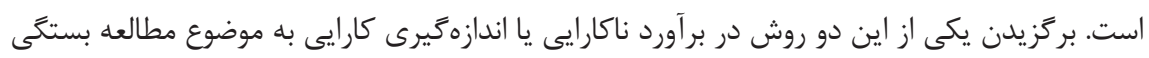

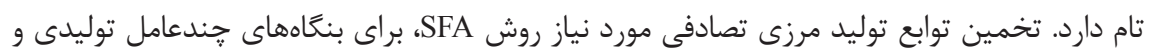

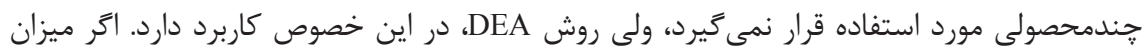

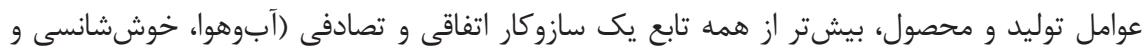

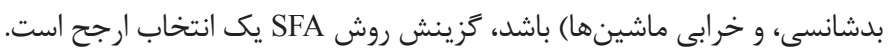

\section{جدول ا: مقايسه روشهاى (SFA) و (DEA)}

\begin{tabular}{|c|c|c|c|}
\hline نتيجه & روش & ويثزى & رديف \\
\hline 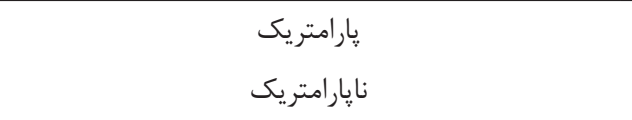 & $\begin{array}{l}\text { (DEA) } \\
(\mathrm{SFA})\end{array}$ & هارامتريك/ نايارامتريك & 1 \\
\hline خلى & $\begin{array}{l}\text { (DEA) } \\
(\mathrm{SFA})\end{array}$ & مد نظر قرار دادن جمله & r \\
\hline برنامهريزى خطى & $\begin{array}{l}\text { (DEA) } \\
(\mathrm{SFA})\end{array}$ & روش تخمين & r \\
\hline 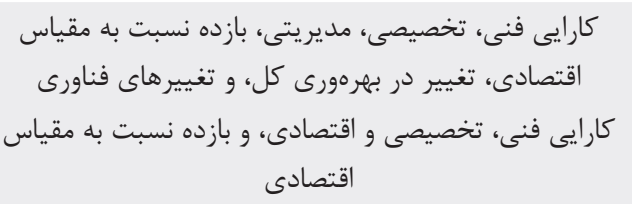 & $\begin{array}{l}\text { (DEA) } \\
\text { (SFA) }\end{array}$ & موارد قابلاندازهيرى & f \\
\hline 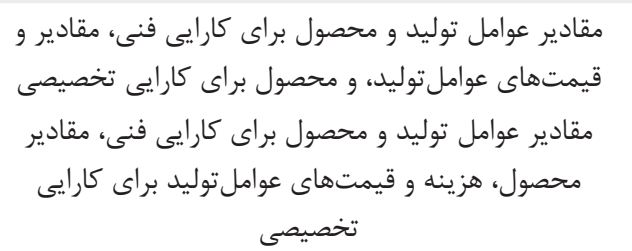 & $\begin{array}{l}\text { (DEA) } \\
\text { (SFA) }\end{array}$ & متغيرهاى مورد نياز & $\Delta$ \\
\hline
\end{tabular}

بهطور خلاصه مىتوان گَفت براى تحليل و اندازمكيرى كارايى دو روش SFA و DEA به صورت

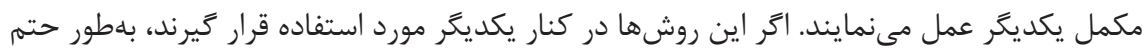
از درجه اعتماد بالايى برخوردار خواهند بود و خواهند توانست مدل مناسبى براى افزايش كار ايى ارائه

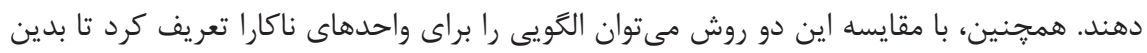


وسيله اين گونه بنحاهها خود را به مرز كارايى برسانند و از منابع و امكانات بلنحو بهينه استفاده كنند.

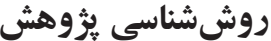

تابع ترانسلاكَ' از اشكال انعطافيذيرى است كه براى تخمين مستقيم تابع توليد بكار مىرود و

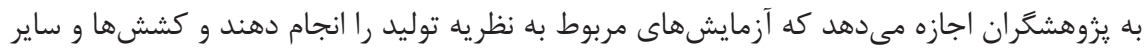
يارامترهاى توليد را تحت يكسرى مفروضهاى اوليه تخمين بزنند. يزوهشها نشان مى نهد كه تابع

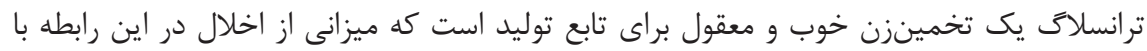

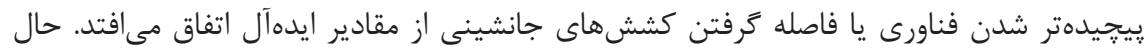

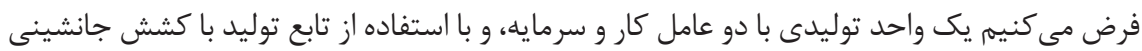

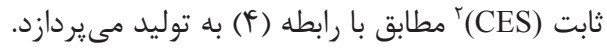

$q=\gamma\left(\delta K^{-\rho}+(1-\delta) L^{-\rho}\right)^{-\gamma / \rho} \quad, \quad \rho \geq 1, \quad \gamma \geq 0 \quad, 0<\delta \prec 1, \mathrm{v} \succ 0$

در رابطه (q) نشانگر مقدار توليد، L نيروى كار، K مقدار سرمايه، v يارامتر بازده نسبت به

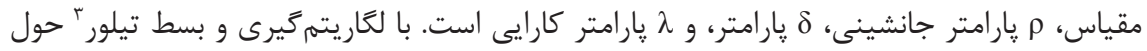

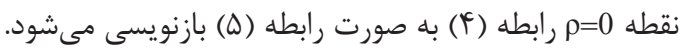

اكنون با توجه به آنكه رابطه بالا غير خطى است، با استفاده از بسط تيلور آن را خطى مى كنيم.

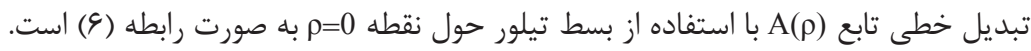

$A(\rho)=A(0)+\rho A^{\prime}(0)+\rho^{\frac{2}{2 !}} A^{\prime \prime}(0)+\ldots$

در رابطه (9)، A' و "A بهترتيب نشانكً مشتقهاى اول و دوم است.

1. Translog Function

2. Constant Elasticity of Substitution

3. Taylor Series 


$$
\begin{aligned}
& A(0)=0 \\
& \mathrm{~A}^{\prime}(0)=-(\delta \log (K)+(1-\delta) \log (L) \\
& A^{\prime \prime}(0)=\delta(1-\delta)(\log (K)-\log (L)
\end{aligned}
$$

$$
\begin{aligned}
\log (q) & =\log (\gamma)+\left(-\frac{v}{\rho}\right)[-\rho(\delta \log (K)+(1-\delta) \log (L) \\
& +\left(\frac{\rho^{2}}{2}\right)(1-\delta)(\log (K)-\log (L))^{2}
\end{aligned}
$$

$$
\log (q)=\beta_{1}+\beta_{2} \log (K)+\beta_{3} \log (L)-\beta_{4}(\log (K)-\log (L))^{2}
$$

بهجاى ضرايب رابطه (^)، در رابطه (9) از ضرايب م با تعاريف زير استفاده مىشود.

$$
\begin{aligned}
& \beta_{1}=\log (\gamma) \\
& \beta_{2}=v \delta \\
& \beta_{3}=-\left(\frac{v}{\rho}\right)(1-\rho) \\
& \beta_{4}=\rho^{2}[2 \delta(1-\delta)]
\end{aligned}
$$

$$
\text { بر اساس اين، تابع ترانسلات براى دو عامل توليد به صورت تابع (• () است: }
$$

$$
\begin{aligned}
\log (q) & =\beta_{0}+\beta_{K} \log \left(P_{K}\right)+\beta_{L} \log \left(P_{L}\right)+\beta_{K} K\left(\log \left(P_{K}\right)\right)^{2} \\
& +\beta_{L} L\left(\log \left(P_{L}\right)\right)^{2}+\beta_{K} L\left(\log \left(P_{k}\right)\right) \log \left(P_{L}\right)
\end{aligned}
$$

استفاده از اين تابع داراى مزيتهايى است مانند: امكان تغيير كشش و مقياس همراه با تغيير محصول و عوامل توليد متناسب با آن وجود دارد؛ تابع تقاضاى عوامل توليد از شيب منفى برخوردار است؛ اثرهاى قيمتى متقاطع وجود دارد؛ تغييرهاى هزينه نهايى و قيمت عوامل توليد برابر با تغييرها در تقاضاى عوامل توليد است؛ مجموع كشش قيمتى كالا و كشش قيمتى متقاطع برابر صفر است؛ افزايش در هزينهها با يك نسبت مشخص مى تواند به افزايش قيمت (هزينه) به همان ميزان بيانجامد،

$$
\text { و در نهايت ميزان توليد را ثابت نته دارد. }
$$


غيرخطى تابع توليد است و يس از تخمين، ضرايب مانند ضرايب تابع كاب-داكلاس معرف كشش

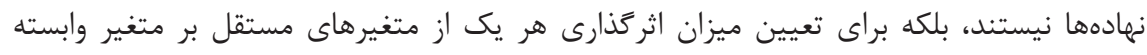

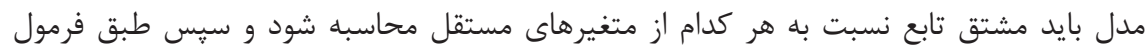
كشش، ميزان كشش متغير مورد نظر برآورد شود، كه اين موضوع بيانكر اين واقعيت است كه ضرايب متغيرهاى مستقل بهتنهايى نشاندهنده ميزان تاثير متغير مستقل بر متغير وابسته مدل نيستند.

$$
\begin{aligned}
& \frac{\partial \operatorname{Ln}(Y)}{\partial \operatorname{Ln}(L)}=\beta_{1}+\beta_{3} \operatorname{Ln}(L)+\beta_{5} \operatorname{Ln}(K) \\
& \frac{\partial \operatorname{Ln}(Y)}{\partial \operatorname{Ln}(K)}=\beta_{2}+\beta_{4} \operatorname{Ln}(K)+\beta_{5} \operatorname{Ln}(L)
\end{aligned}
$$

$$
\begin{aligned}
& \frac{d \operatorname{Ln}(Y)}{d \operatorname{Ln}(L)}=\frac{\partial \operatorname{Ln}(Y) / Y}{\partial \operatorname{Ln}(L) / L}=\frac{\partial \operatorname{Ln}(Y)}{\partial \operatorname{Ln}(L)} \times \frac{L}{Y}=\left[\beta_{1}+\beta_{3} \operatorname{Ln}(L)+\beta_{5} \operatorname{Ln}(K)\right] \times\left(\frac{L}{Y}\right) \\
& \frac{d \operatorname{Ln}(Y)}{d \operatorname{Ln}(K)}=\frac{\partial \operatorname{Ln}(Y) / Y}{\partial \operatorname{Ln}(K) / K}=\frac{\partial \operatorname{Ln}(Y)}{\partial \operatorname{Ln}(K)} \times \frac{K}{Y}=\left[\beta_{2}+\beta_{4} \operatorname{Ln}(K)+\beta_{5} \operatorname{Ln}(L)\right] \times\left(\frac{K}{Y}\right)
\end{aligned}
$$

تابع توليد ترانسلاك كه در اين يروهش مورد استفاده قرار مى گيرد به شكل تابع (rا () است:

$$
\begin{aligned}
\operatorname{Ln}(Q) & =\beta_{0}+\beta_{\mathrm{L}} \operatorname{Ln}(L)+\beta_{\mathrm{K}} \operatorname{Ln}(K)+\beta_{\mathrm{E}} \operatorname{Ln}(E)+\beta_{\mathrm{LK}} \operatorname{Ln}(L) \times \operatorname{Ln}(K) \\
& +\beta_{\mathrm{LE}} \operatorname{Ln}(L) \times \operatorname{Ln}(E)+\beta_{\mathrm{KE}} \operatorname{Ln}(K) \times \operatorname{Ln}(E)+\frac{1}{2} \beta_{\mathrm{LL}} \operatorname{Ln}(L)^{2} \\
& +\frac{1}{2} \beta_{\mathrm{KK}} \operatorname{Ln}(K)^{2}+\frac{1}{2} \beta_{\mathrm{EE}} \operatorname{Ln}(E)^{2}+U_{i}-V_{i}
\end{aligned}
$$

$$
\text { كه در آن: }
$$

ارز شافزوده هر بخش صنعت به تفكيك كدهاى جهار رقمى ISIC: است، L: تعداد نيروى كار استفادهده در هر گروه است، E: ارزش انواع سوخت و برق مصرفشده در بخشهاى مختلف صنعت

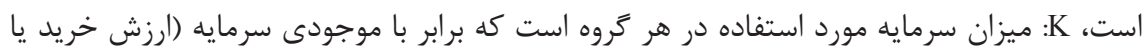
تحصيل اموال سرمايهاى و هزينه تعميرات اساسى اموال سرمايهاى منهاى ارزش فروش يا انتقال اموال

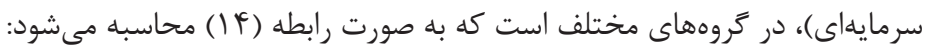
$K_{t+1}=(1-\rho) K_{t}+I_{t+1}$ 


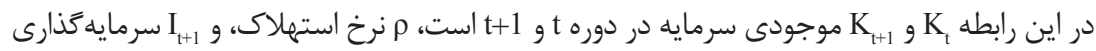

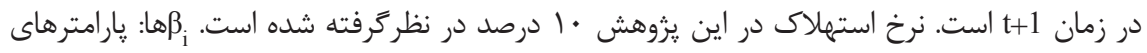
مدل هستند و بايد تخمين زده شوند. U و U U توابع مرزى به صورت يارامتريك و نايارامتريك امكان يذير است. در روش نإِارامتريك، اثرهاى تصادفى در سنجش كارايى لحاظ نمى تابع توليد يا بالاى تابع مرزى محاسبهشده مشاهده گردد، اين نقاط توسط روش نايارامتريك توجيهيذير

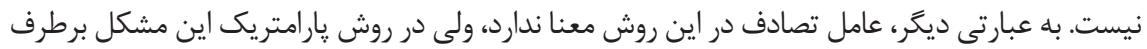

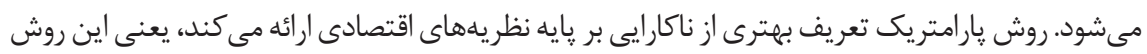

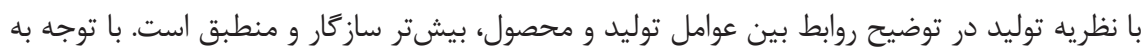

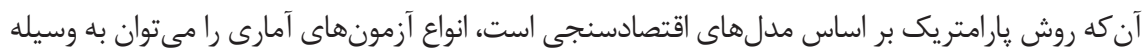

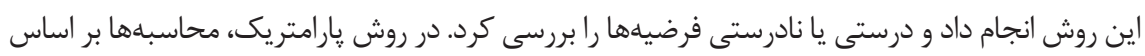

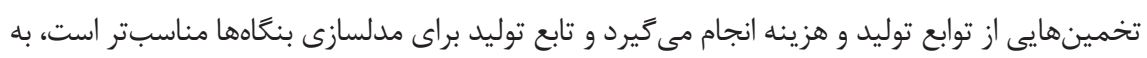

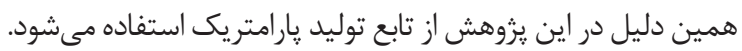
برترى مدلهاى مرزى تصادفى نسبت به مدلهاى معمولى اقتصادسنجى در اين است كه در برازش

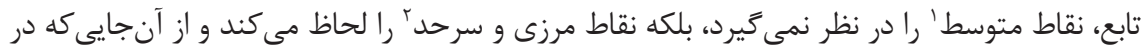

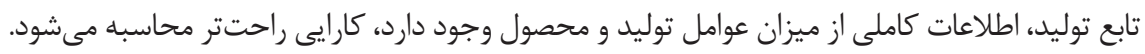

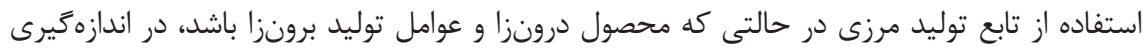
ناكارايى تخصيصى و ناكارايى فنى روش مناسبى است. بهترين راهحل تخمين تابع توليد با استفاده از

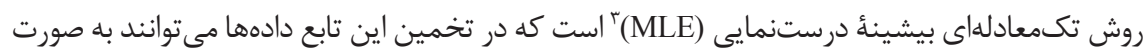

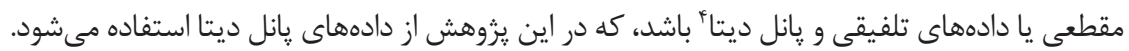

\section{دادهoا}

دادهها و اطلاعات مورد استفاده در اين يزوهش از آمار و اطلاعات كاركاههاى صنعتى داراى .

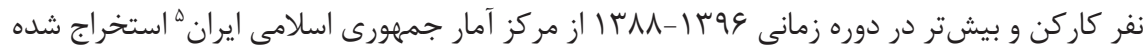

1. Average

2. Frontier

3. Maximum Likelihood Estimation

4. Panel Data

5. www.amar.org.ir 
است، و متغيرهايى مانند ارزشافزوده (ميليون ريال)، انرزى (ميليون ريال)، ميزان سرمايه (ميليون

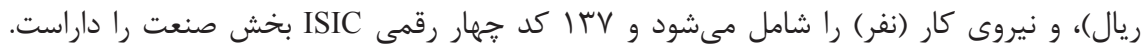
دادهاى يزوهش به صورت دادههاى پانل در ينج گروه تقسيهبندى مى شوند. در دستهبندى كدهاى

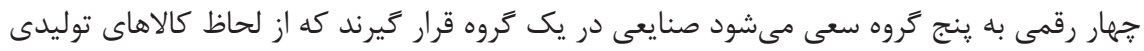
و مواد اوليه مورد استفاده، بيشترين شباهت را به يكديكر داشته باشند. بدين منظور، بخش صنش صنعت

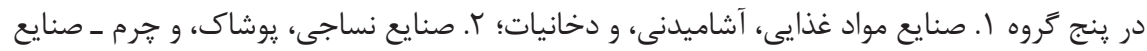

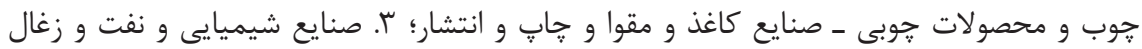

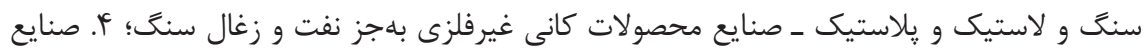

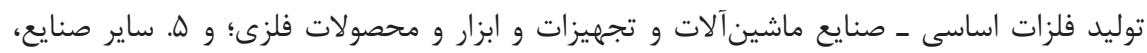
تقسيممبندى مىشود.

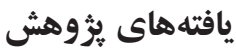

در اين يزوهش با استفاده از نرمافزار FRONTIER' و روش تحليل مرزى تصادفى، ابتدا تابع

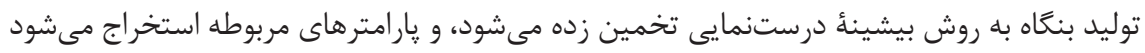

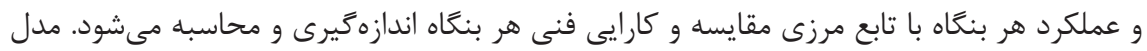

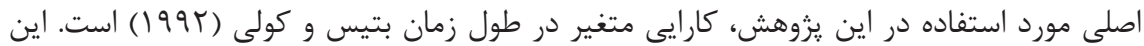
الكو، قابليت تطبيق با دادهاى مقطعى، تلفيقى، كارايى متغير و غيرمتغير در طول زمان، تابع توليد،

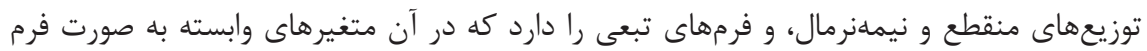

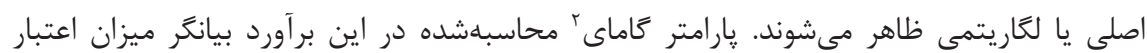

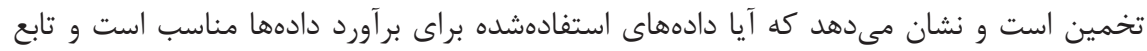
مرزى تصادفى براى مجموعهاى از مشاهدهها كه در دسترس است، برآورديذير است يا خير؟ و آر آر

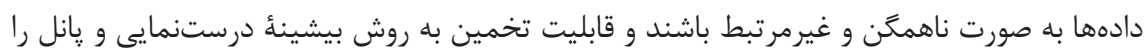

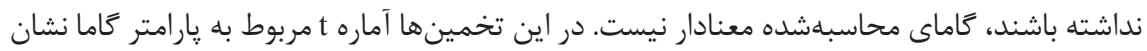
مى دهد كه روش مرزى تصادفى در بيشتر مواقع در سطوح بسيار بالايى معنادار است، پِ ميى متوان

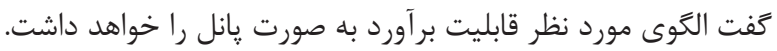

1. Frontier 4.1 (Software for Stochastic Frontier Analysis)

2. Gamma 
جدول ז: برآورد تابع توليد

\begin{tabular}{|c|c|c|c|}
\hline آماره t & ضريب & توضيح & يار امتر \\
\hline$F / D \mid$ & $11 / 11$ & عرض از مبدا & $\beta_{0}$ \\
\hline$-r / I T$ & $-r / \cdot 1$ & $\operatorname{Ln}(\mathrm{L})$ & $\beta_{\mathrm{L}}$ \\
\hline$-r / \cdot V$ & $-T / F T$ & $\operatorname{Ln}(\mathrm{K})$ & $\beta_{\mathrm{K}}$ \\
\hline $1 / \Delta \Lambda$ & $r / M F$ & $\operatorname{Ln}(E)$ & $\beta_{\mathrm{E}}$ \\
\hline ( & $1 / N T$ & $1 / 2(\mathrm{~L}) 2$ & $\beta_{\mathrm{LL}}$ \\
\hline $1 / T \Delta$ & $\cdot / 4 \Lambda$ & $1 / 2(\mathrm{~K}) 2$ & $\beta_{\mathrm{KK}}$ \\
\hline T/r & T/IV & $1 / 2(E) 2$ & $\beta_{\mathrm{EE}}$ \\
\hline$r / 1 \Lambda$ & $1 / F \Delta$ & $\operatorname{Ln}(\mathrm{L} * \mathrm{~K})$ & $\beta_{\mathrm{LK}}$ \\
\hline$-T / \Gamma \varphi$ & $-r / \cdot \Lambda$ & $\operatorname{Ln}(L * E)$ & $\beta_{\mathrm{LE}}$ \\
\hline$-1 / 91$ & $-1 / 11$ & $\operatorname{Ln}\left(K^{*} E\right)$ & $\beta_{\mathrm{KE}}$ \\
\hline \multirow[t]{7}{*}{$\Delta r / F q$} & $\cdot|\Lambda|$ & Gamma & آماره كَاما \\
\hline & $\cdot 149$ & & $\sigma_{\mathrm{s}}^{2}$ \\
\hline & $-99 / T \Delta$ & & لكًاريتم درستنمايى \\
\hline & rq/IT & & آماره آزمون لاكرانز \\
\hline & 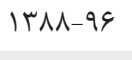 & & دوره زمانى \\
\hline & $\Delta$ & & تعداد مقاطع \\
\hline & $i \Delta$ & & تعداد مشاهدهها \\
\hline
\end{tabular}

تخمين كارايى توليد در بخش صنعت

يس از محاسبه تابع توليد بخش صنعت مىتوان با استفاده ار تابع مرزى تصادفى برآوردشده، عملكرد و ميزان انحراف هر كروه صنعتى با بهتر ين عملكرد صنعت مقايسه و محاسبه شود، كه نتايج

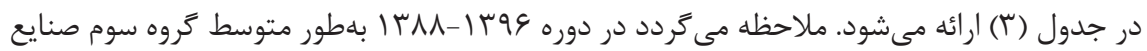
شيميايى و نفت و زغال سنَ و لاستيك و يلاستيك، و همجنين صنايع محصولات كانى غيرفلزى بهجز نفت و زغال سنَ بيشترين كارايى را در ميان ساير كروهها دارند، يعنى اين گروه، از منابع

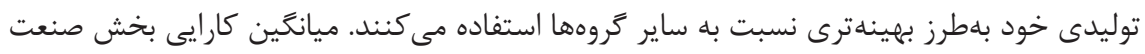

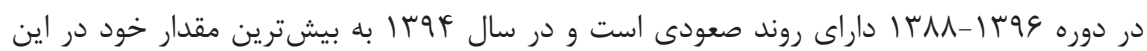


مورد مىرسد. بنابراين، مىتوان كَفت عملكرد بنكًاهها در استفاده از عوامل توليدىشان در دوره مورد بررسى بهبود مىيابد و منابع را بهينهتر استفاده مى كنند كه متوسط كارايى توليد صنايع كشور را از مورد

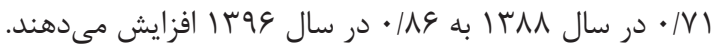

جدول "ا: تخمين كارايى توليد بخش صنعت

\begin{tabular}{|c|c|c|c|c|c|c|c|c|c|c|c|c|}
\hline متوسط & פוg & Irad & Irgp & Irar & Irar & $|r a|$ & irq. & IrA9 & ITA & كروه & فعاليت & مرتبه \\
\hline $.19 V$ & .199 & .199 & .191 & .191 & .191 & $.19 \mathrm{~V}$ & .198 & $1 / 99$ & .190 & & گروه سوم & \\
\hline$\cdot / 1 f$ & $\cdot 1 \cdot$ & $-r / \cdot F$ & $\cdot / \cdot$ & $\cdot 1 \cdot$ & I/Ir & $.1 \cdot$ & $1 / 10$ & $1 / 19$ & & r & نرخد رشاليانه (درصد) & 1 \\
\hline .194 & .190 & .194 & .199 & .190 & .194 & .194 & . 194 & $.19 r$ & $\cdot 119$ & & ووه جهارم & \\
\hline - IAT & $1 / \cdot 9$ & $-r / \cdot \Lambda$ & $1 / \cdot \Delta$ & $1 / \cdot 9$ & $\cdot 1 \cdot$ & $1 / \cdot 1$ & $1 / \cdot 9$ & r/rV & & f & نرخد رشد & $r$ \\
\hline - /A9 & .194 & .194 & .191 & .191 & $\cdot 1199$ & $\cdot / \Lambda \Delta$ & •lAr & . /VA & •/V & & گروه اول & \\
\hline$r / 9 V$ & $\cdot 1 \cdot$ & $1 / 1$. & $\cdot 1 \cdot$ & $r / T \Delta$ & $F / V I$ & $r / f \mid$ & $G|f|$ & s/AD & & 1 & نرخد رشد & r \\
\hline . IV 9 & $\cdot 1 \Lambda$ & $\cdot|\Lambda|$ & $\cdot / \wedge D$ & $\cdot|1|$ & $\cdot 11$ & $\cdot / V 9$ & $\cdot / V Y$ & $\cdot 19 V$ & . & & گروه دوم & \\
\hline$r / l$ & $-1 / T \pi$ & $-9 / V I$ & p/94 & $1 / T \Delta$ & $\Delta / r \varphi$ & $\Delta / \Delta \varphi$ & $V / F G$ & $\varepsilon / \pi \Delta$ & & r & نرخ رشد & f \\
\hline • & $.19 \mathrm{~V}$ & $\cdot 19 \mathrm{~V}$ & .199 & $\cdot|9|$ & $\cdot \mid \Delta \varphi$ & $\cdot / 4 V$ & . IFT & ع & $\cdot / \pi \Delta$ & & حروه ينجم & \\
\hline$\Lambda / 90$ & $.1 \cdot$ & $1 / \Delta T$ & $\Lambda / r \cdot$ & N/9r & $19 / 10$ & $11 / 9$. & $1919 \mathrm{~V}$ & r/AG & & $\Delta$ & نرخد رشد & $\Delta$ \\
\hline$\cdot|\Lambda|$ & · IA૬ & - /19 & $\cdot / \Lambda \mathrm{V}$ & $\cdot / \Lambda \Delta$ & . IAr & $\cdot 1 \Lambda$ & $\cdot / V V$ & $\cdot / V F$ & $\cdot|V|$ & & متوسط & \\
\hline r/rq & $-\cdot 1 \cdot f$ & $-1 / \lambda r$ & $r / \Delta \Delta$ & $r|\Lambda|$ & G/ & F/gr & $\varphi / \Delta \varphi$ & $r / f \mid$ & & & نرخ رشد (درد & متوسط \\
\hline
\end{tabular}

رتبه اول كارايى توليد در صنايع شيميايى و نفت و زغال سنگ، لاستيك، پِلاستيك و صنايع

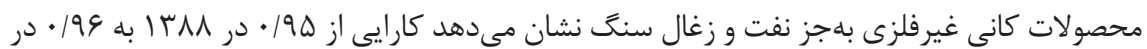

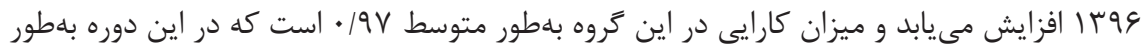

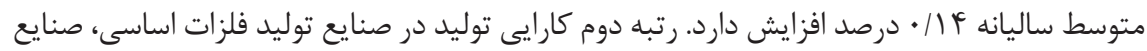

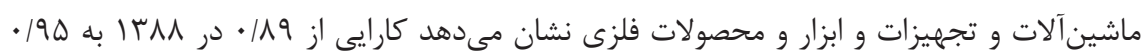


در צجا افزايش دارد، ميزان كارايى در اين گروه بلهور متوسط ه9/• است، و در دوره مورد بررسى

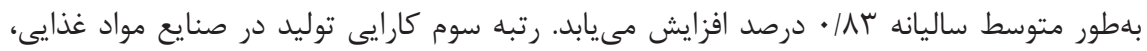
آشاميدنى، و دخانيات نشان مىدهد كارايى توليد از

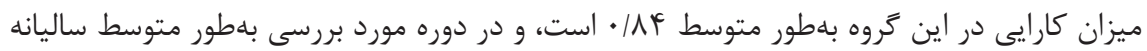
r/VV

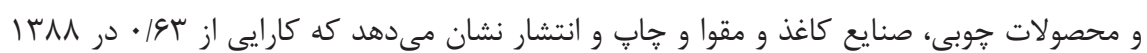

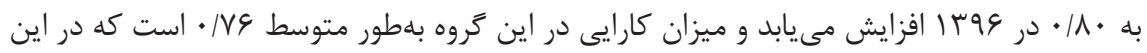

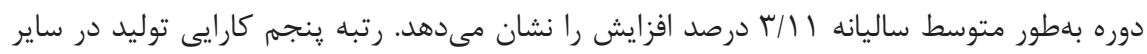

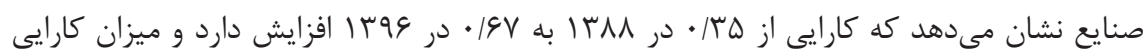

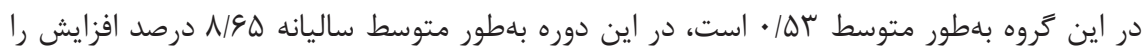
نشان مى ندهد.

\section{بحث و نتيجه Fيرى}

هدف اين يزوهش، تجزيهوتحليل و رتبابندى كارايى فنى بخش صنعت ايران به تفكيك كد جهار

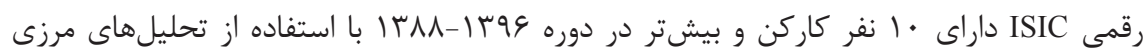
تصادفى است. براى دستيابى به اين هدف، با استفاده تابع توليد مرزى تصادفى (SFA)، و تكنيكهاى

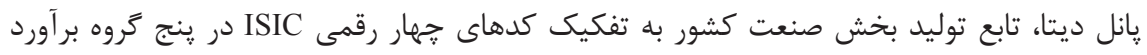

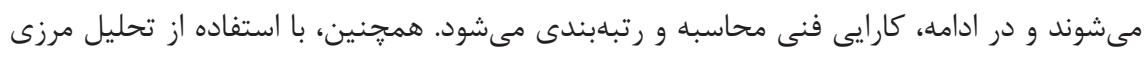

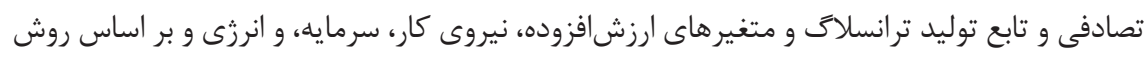

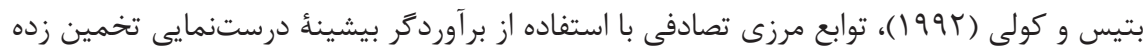
مىشود، و در ادامه كارايى فنى محاسبه و رتبهبندى مى مَّردد.

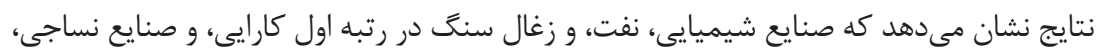

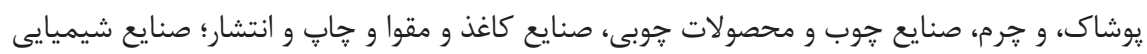

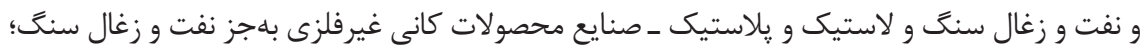

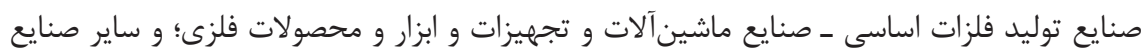

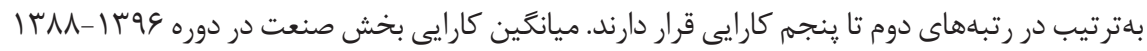

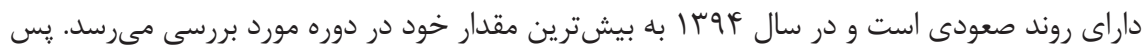


مى توان كفت عملكرد بنعاهها در استفاده از عوامل توليدى خود در دوره مورد بررسى بهبود مىيابد و منابع را بهينهتر استفاده مى كنند كه متوسط كارايى توليد صنايع كشور را افزايش مى دهدد.

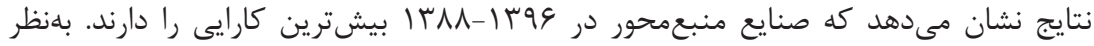
مىرسد يايين بودن هزينههاى مواد اوليه و انرزى، عامل اصلى ايجاد اين كارايى است. وجود جنين

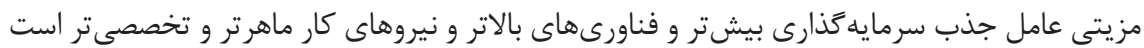

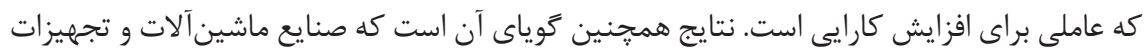
و ابزار در رتبه دوم كارايى در ميان صنايع كشور در دوره مورد بررسى قرار دارند كه در تحليل اين

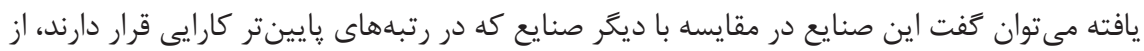

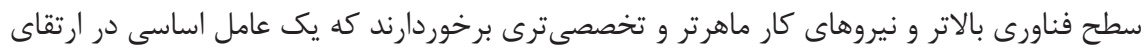

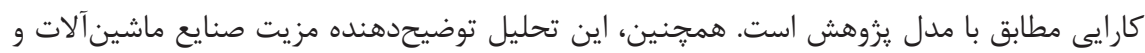
تجهيزات و ابزار نسبت به صنايع غذايى است كه در رتبه سوم كارايى قرار مى كيرند.

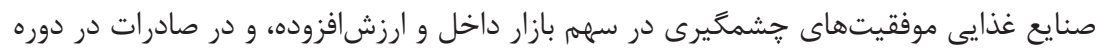

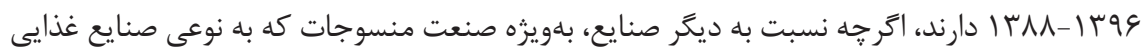
جايكزين سههم آن در دوره پِيشين است، كارايى بالاترى دارند ولى به جهت سطح كارايى پايينتر

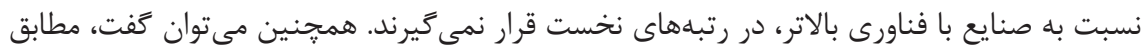

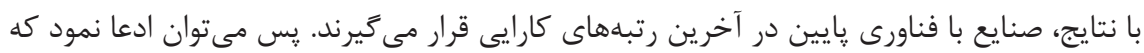
فناورى عامل كليدى در جَّونكى استفاده از عوامل سهكانه نيروى كار، موجودى سرمايه، و انرزى در تابع توليد ترانسلاك است و نقش خود را در تركيب عوامل با افزايش مطلق يا نسبى توليد نشان

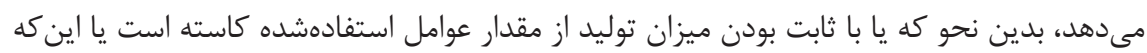
با ثابت بودن عوامل به ميزان توليد بيشترى انجاميده است كه امكان بهترين شكل استفاده از عوامل توليد، يعنى كاراترين حالت بكاركيرى منابع را فراهم مىسازد كه نشان مىدهد تخصصى شدن نيروى

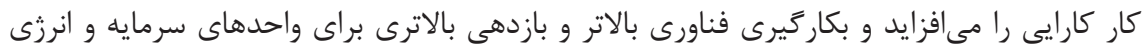

$$
\text { بلهدست مى آورد. }
$$

اين يزوهش با ساير يزوهش ها در مواردى جون دوره زمانى، استفاده از كدهاى جهار رقمى ISIC داراى • ا نفر كاركن و بيشتر، دستهبندى فعاليتهاى صنعتى شبيه به هم در يك گروه، استفاده از

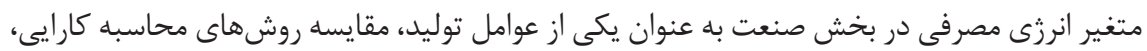

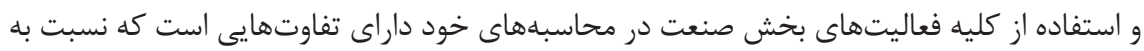


يزوهشهاى ييشين سهمى متفاوت در توليد ادبيات تجربى موضوع مورد نظر دارد.

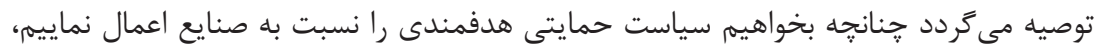

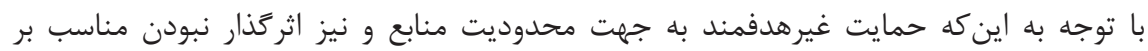

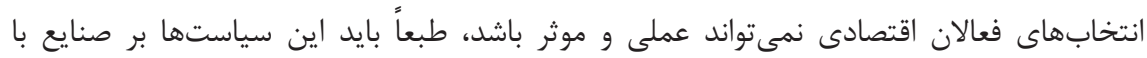

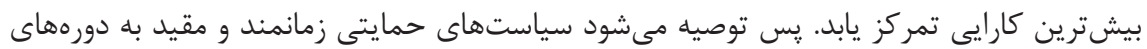

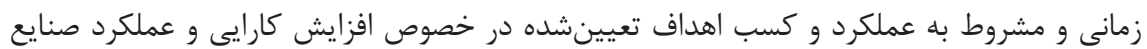
در اين شاخص باشد. با توجه به عامل فناورى و بكارگيرى فناورىهاى بالا كه مىتواند مسير مناسبى براى ارتقاى كارايى باشد، توصيه مى

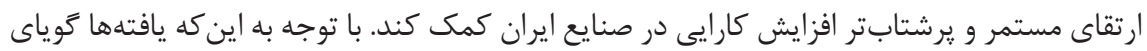

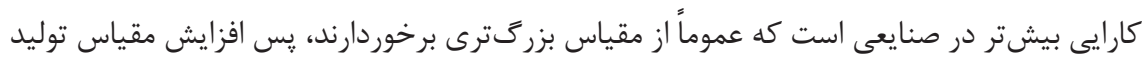

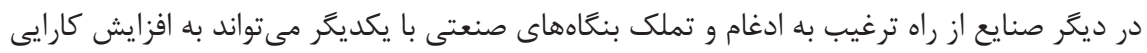

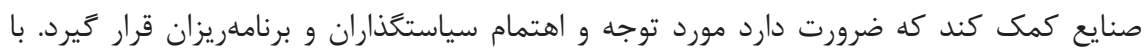

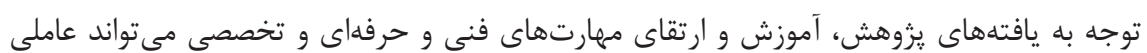
در ارتقاى كارايى صنايع و نيز جابهجايى نيروهاى بين صنايع باشد كه توصيه مىشود مورد تورد توجه

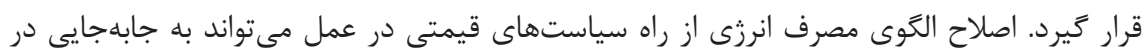

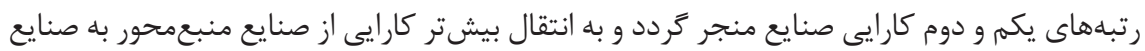

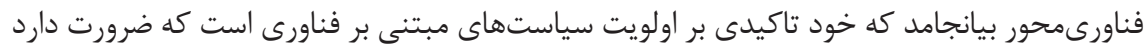

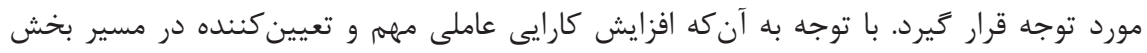

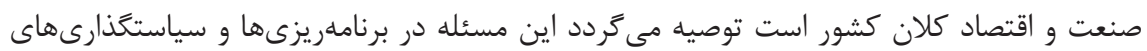
صنعتى و اقتصادى مورد توجه قرار كيرد. شدت مصرف انرزى يكى از عوامل موثر بر ناكارايى در بخش صنعت كشور است كه ضرورت دارد مصرف انرزى بخش صنعت كشور در قالب برنامههاى بهينهسازى مصرف سوخت صنايع در نظر گرفته شود.

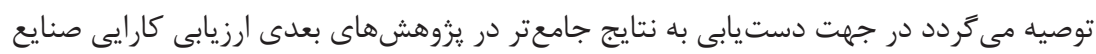

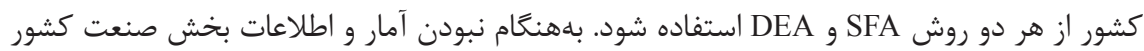
ايران يكى از محدوديتهاى اين گونه يزوهشها بهشمار مىرود. 


\section{منابع \\ الف) فارسى}

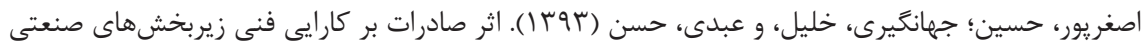

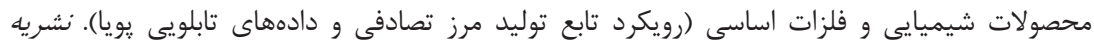

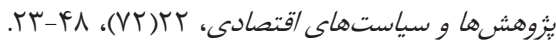

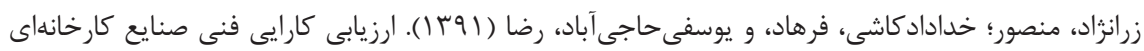

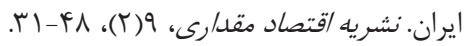

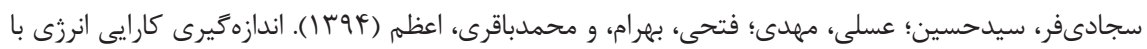

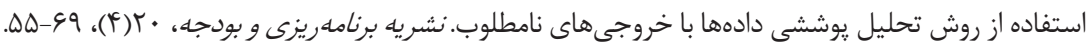

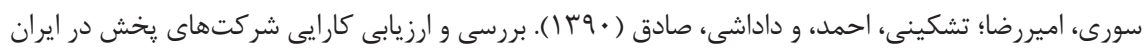

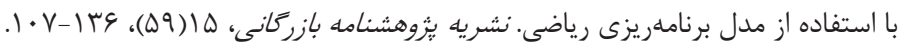

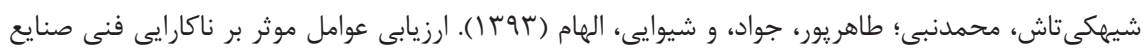

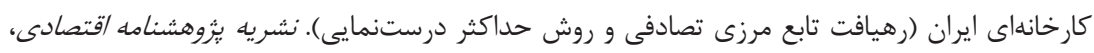
.YY-FY،(QY))F

غلامى، راضيه، و مهرابى بشرآبادى، حسين (ه (1) (1). بررسى اثر مالكيت و مديريت دولتى بر ناكارايى صنايع

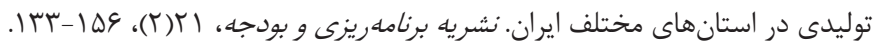

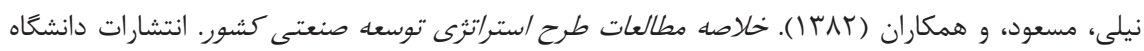
صنعتى شريف و انتشارات علمى.

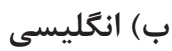

Aigner, D., Lovell, C. K., \& Schmidt, P. (1977). Formulation and Estimation of Stochastic Frontier Production Function Models. Journal of Econometrics, 6(1), 21-37.

Battese, G. E., \& Coelli, T. J. (1992). Frontier Production Functions, Technical Efficiency and Panel Data: With Application to Paddy Farmers in India. Journal of Productivity Analysis, 3(1-2), 153-169.

Bigsten, A., Collier, P., Dercon, S., Fafchamps, M., Gauthier, B., Gunning, J. W., ... Pattillo, C. (2000). Exports and Firm-Level Efficiency in African Manufacturing: University of Oxford, Institute of Economics and Statistics. WPS/2000-16

Çalmaşur, G. (2016). Technical Efficiency Analysis in the Automotive Industry: A Stochastic Frontier Approach. International Journal of Economics, Commerce and Management, 4(4), 120-137.

Charnes, A., Cooper, W. W., \& Rhodes, E. (1978). Measuring the Efficiency of Decision Making Units. European Journal of Operational Research, 2(6), 429-444. 
Coelli, T. J., Rao, D. P., O’Donnell, C. J., \& Battese, G. E. (1998). An Introduction to Productivity and Efficiency Analysis. Springer Science: New York.

Cornwell, C., Schmidt, P., \& Sickles, R. C. (1990). Production Frontiers with CrossSectional and Time-Series Variation in Efficiency Levels. Journal of Econometrics, 46(1-2), 185-200.

Debreu, G. (1951). The Coefficient of Resource Utilization. Econometrica: Journal of the Econometric Society, 19(3), 273-292.

Fahmy-abdullah, M., Sieng, L. W., \& Isa, H. M. (2018). Technical Efficiency in Malaysian Textile Manufacturing Industry: A Stochastic Frontier Analysis (SFA) Approach. International Journal of Economics \& Management, 12(2), 407-419.

Farrell, M. J. (1957). The Measurement of Productive Efficiency. Journal of the Royal Statistical Society: Series A (General), 120(3), 253-281.

Greene, W. (2005). Fixed and Random Effects in Stochastic Frontier Models. Journal of Productivity Analysis, 23(1), 7-32.

Hayek, F. A. (1949). The Meaning of Competition, Individualism and Economic Order: London, Routledge \& Kegan Paul.

Hirshleifer, J., \& Glazer, A. (1992). Price Theory and Applications: Prentice Hall.

Jondrow, J., Lovell, C. K., Materov, I. S., \& Schmidt, P. (1982). On the Estimation of Technical Inefficiency in the Stochastic Frontier Production Function Model. Journal of Econometrics, 19(2-3), 233-238.

Koopmans, T. (1951). Activity Analysis of Production and Allocation. John Wiley and Sons. New York.

Kumbhakar, S. C. (1990). Production Frontiers, Panel Data, and Time-Varying Technical Inefficiency. Journal of Econometrics, 46(1-2), 201-211.

Meeusen, W., \& Van Den Broeck, J. (1977). Efficiency Estimation from Cobb-Douglas Production Functions with Composed Error. International Economic Review, 18(2), 435-444.

Mohd Noor, Z., \& Ismail, R. (2007). Technical Efficiency Analysis in Small and Medium Scale Industry in Malaysia. International Journal of Management Studies (IJMS), 14(1), 199-218.

Mok, V., Yeung, G., Han, Z., \& Li, Z. (2007). Leverage, Technical Efficiency and Profitability: An Application of DEA to Foreign-Invested Toy Manufacturing Firms in China. Journal of Contemporary China, 16(51), 259-274.

Pitt, M. M., \& Lee, L.-F. (1981). The Measurement and Sources of Technical Inefficiency in the Indonesian Weaving Industry. Journal of Development Economics, 9(1), 43-64.

Quesada, G. P. (2017). Technical Efficiency of Dairy Farms in Uruguay: A Stochastic Production Frontier Analysis. The International Conference on Decision Economics,

Shephard, R. (1953). Cost and Production Functions. Princeton University Press. Princeton, NJ.

Singh, A. (1977). UK Industry and the World Economy: A Case of De-Industrialisation? Cambridge Journal of Economics, 1(2), 113-136.

Sumanth, D. J. (1984). Productivity Engineering and Management: Productivity Measurement, Evaluation, Planning, and Improvement in Manufacturing and Service Organizations: McGraw-Hill College. 